\title{
Taenia solium cysticercosis in West Africa: status update
}

\author{
Jihen Melki ${ }^{1}$, Eugène Koffi ${ }^{1}$, Marcel Boka ${ }^{2,3}$, André Touré ${ }^{1}$, Man-Koumba Soumahoro ${ }^{1}$, and Ronan Jambou ${ }^{1,4, *}$ \\ ${ }^{1}$ Institut Pasteur de Côte d'Ivoire, B.P. 490, Abidjan 01, Côte d'Ivoire \\ 2 Direction des Services Vétérinaires, Ministère des Ressources Animales et Halieutiques, B.P. V84, Abidjan 01, Côte d'Ivoire \\ ${ }^{3}$ Université Alassane Ouattara, Ministère de l'Enseignement Supérieur et de la Recherche Scientifique, B.P. V18, Bouaké 01, \\ Côte d'Ivoire \\ ${ }^{4}$ Institut Pasteur, 25-28 Rue du Dr Roux, 75015 Paris, France
}

Received 24 April 2018, Accepted 6 August 2018, Published online 18 September 2018

\begin{abstract}
Cysticercosis is caused by the larvae of the cestode Taenia solium. Few data are available on the prevalence of this disease in pigs and humans in West African countries. The aim of this study was to provide an overview of existing data concerning the spread of this parasitosis in the countries of the Economic Community of West African States (ECOWAS) on the basis of the literature published over the last five decades. Systematic searches for publications were carried out on PubMed and Google Scholar, as well as in certain regional and local journals. From a total of 501 articles initially retrieved concerning T. solium cysticercosis in West African countries, only 120 articles were relevant for this review and therefore finally retained. For pigs, only eight out of sixteen countries of the region have reported porcine cysticercosis. Post-mortem examination of carcasses at slaughterhouses, meat inspection at butcheries or tongue inspection in herds have been the main source of data, but may not entirely reflect actual parasite distribution. For humans, only five out of sixteen countries reported epidemiological data on neurocysticercosis. Most data referred to neurocysticercosis prevalence among epileptic patients or isolated clinical cases. Furthermore, existing data are often old. Overall, T. solium cysticercosis remains largely neglected in West Africa, and its prevalence appears not to be affected by any religion in particular. There is an urgent need to promote and implement health partnerships and programs on this disease in order to collect more data and identify sensitive populations in the countries of the ECOWAS area.
\end{abstract}

Key words: Cysticercosis, Taenia solium, West Africa, epilepsy, pig.

Résumé - La cysticercose à Taenia solium en Afrique de l'Ouest : état des lieux. La cysticercose est causée par les larves du cestode Taenia solium. Peu de données sont disponibles sur la prévalence de cette maladie chez les porcs et les humains dans les pays d'Afrique de l'Ouest. Le but de cette étude est de fournir un aperçu des données existantes concernant la propagation de cette parasitose dans les pays de la Communauté économique des États de l'Afrique de l'Ouest (CEDEAO) sur la base de la littérature publiée au cours des cinq dernières décennies. Des recherches systématiques de publications ont été effectuées sur PubMed, Google Scholar, ainsi que sur certaines revues régionales et locales. Sur un total de 501 articles initialement récupérés et concernant la cysticercose à T. solium dans les pays d'Afrique de l'Ouest, seuls 120 articles étaient pertinents pour cet examen et ont donc finalement été retenus. Pour les porcs, seulement huit des seize pays de la région ont signalé une cysticercose porcine. L'examen post mortem des carcasses dans les abattoirs, l'inspection de la viande dans les boucheries ou l'inspection de la langue dans le troupeau ont été la principale source de données, mais peuvent ne pas refléter entièrement la répartition réelle des parasites. Pour l'homme, seuls cinq pays sur seize ont rapporté des données épidémiologiques sur la neurocysticercose. La plupart des données se référaient à la prévalence de la neurocysticercose chez les épileptiques ou les cas cliniques isolés. De plus, les données existantes sont souvent anciennes. Dans l'ensemble, la cysticercose à $T$. solium reste largement négligée en Afrique de l'Ouest et sa prévalence ne semble être affectée par aucune religion en particulier. Il est urgent de promouvoir et de mettre en œuvre des partenariats et des programmes de santé sur cette maladie afin de collecter davantage de données et d'identifier les populations sensibles dans les pays de la zone CEDEAO.

\footnotetext{
*Corresponding author. rjambou@pasteur.fr
}

This is an Open Access article distributed under the terms of the Creative Commons Attribution License (http://creativecommons.org/licenses/by/4.0), which permits unrestricted use, distribution, and reproduction in any medium, provided the original work is properly cited. 


\section{Introduction}

Cysticercosis is a parasitic infection caused by the metacestode larval stage (Cysticercus) of Taenia solium [51]. The life cycle of T. solium is complex and requires two mammalian hosts: pigs and humans are intermediate hosts, whereas only humans are definitive hosts. Humans develop taeniasis through the consumption of raw or undercooked pork containing tapeworm larvae. In animal cysticercosis, tapeworm eggs are ingested with water and food. In human cysticercosis, an additional mode of transmission of the disease is autoinfection through hand-to-mouth contact with hands contaminated by (human) infected feces [54, 105]. Once in the mammalian host, the eggs mature into oncospheres, cross the intestinal wall, enter the bloodstream, and reach the host tissues where the metacestodes evolve into cysticerci [109]. When larvae are located in the brain, the infection is called neurocysticercosis (NCC), a frequent cause of epilepsy or epileptic seizures [99]. Autoinfection is frequent in humans. In West Africa, while a high prevalence of cysticercosis in pigs and humans has occasionally been reported, there is a lack of a consistent and systematic approach in the study of the disease, which may result in a misestimation of its prevalence [123]. West Africa is approximately 6 million $\mathrm{km}^{2}$ in area, covering $20 \%$ of the African continent [122]. It includes 16 countries, namely: Mauritania, Cape Verde, Ghana, Côte d'Ivoire, Senegal, Benin, Togo, Mali, Guinea, Niger, Liberia, Burkina Faso, Nigeria, The Gambia, Guinea Bissau and Sierra Leone. The West African population is about 368 million inhabitants [40], $46 \%$ of whom are concentrated in urban centers and more than $27 \%$ in Nigeria's urban centers only [40, 66]. Rapid urbanization due to natural population growth and rural-urban migration has resulted in proliferation of slum areas with high population densities (e.g. Abuja, Nigeria), poor sanitation, and very low-standard housing. Population movements from rural to urban areas, often coupled with the lack of an adequate water supply and sewage systems, have facilitated the transmission of parasitic infections [78, 100].

Each West African country has its own particular history with diverse ethnic groups and an array of different languages, cultures and customs [87, 113]. Political and social factors affect the resources of the population and, therefore, their health and hygiene conditions. Nigeria has the largest economy in the area on account of its natural and agricultural resources [40]. Ghana and Senegal have benefited from a certain level of stability, enabling their economies to grow and develop [24]. Conversely, countries like Côte d'Ivoire, Guinea Bissau, Liberia, and Sierra Leone were crippled, for decades, by violent conflicts and civil wars causing socio-economic disruption, which made it extremely difficult to conduct health surveys [47]. Some of the countries that experienced civil wars, e.g. Guinea, Liberia and Sierra Leone, were also heavily affected by the Ebola outbreak [117].

The West African area is traversed by the "African Transition Zone" and divided into two regions: (1) the northern region, extending up to the Sahara Desert, and (2) the southern region, extending down to the tropics [20]. This Transition Zone also serves as a transition line between culture and religion: while Christianity is dominant in the south, Islam appears to be more common in the north (e.g. Niger, Mali, Burkina Faso and Mauritania) [34, 88]. This may therefore explain, at least in part, the difference in data availability on cysticercosis between south and north.

Climate can also shape parasite transmission [50]. The arid zone includes northern parts of Senegal, parts of Mali, Burkina Faso and Niger. The semi-arid zone covers the southern parts of Senegambia, Mali, Burkina Faso, Niger, and upper parts of Guinea-Bissau, Guinea, Togo, Benin and Nigeria. The sub-humid zone includes Guinea-Bissau, upper parts of Guinea, the southernmost parts of Mali and Burkina Faso and the northern parts of Ghana, Côte d'Ivoire, Sierra Leone, Benin and the central parts of Nigeria. Vegetation zones run parallel to each other, from north to south, and are related to rainfall quantity [50].

The high level of heterogeneity of the area seems to influence the transmission of the disease and could therefore explain the irregular prevalence of cysticercosis throughout the region. This review tries to shape the pattern of the disease in this area in relation with this heterogeneity. In the meantime, it highlights the scarcity of data available on T. solium cysticercosis and supports the need for more studies.

\section{Methods}

This review covered all the 16 West African countries. The data on cysticercosis in West Africa were collected from: (1) peer-reviewed articles on T. solium cysticercosis in Africa, (2) grey literature consisting of written materials such as theses and dissertations obtained from Google Scholar, and (3) published reports regarding $T$. solium posted by United Nationsrelated agencies such as WHO, FAO, or OIE, and the Centers for Disease Control and Prevention (CDC).

The following search strategy was applied: (1) in PubMed, using the Boolean operator AND, the terms "cysticercosis", "Taenia solium" and "West Africa" (and each individual country name); (2) in Google Scholar (ahttp://scholar.google. com), the terms "cysticercosis Taenia solium" were screened in the full core texts and not only in titles and keywords. Thereafter, several Google searches were performed in respect of the various countries of the region and key words and expressions such as "porcine cysticercosis", "human cysticercosis", "neurocysticercosis", "Taenia solium", "T. solium", and "cysticercosis" were searched in order to retrieve scientific publications on cysticercosis relating to each country. Additionally, some other internet websites, such as The Journal of Infection in Developing Countries (https://www.jidc.org), Société de Pathologie Exotique (http://www.pathexo.fr) and African Journals Online (https://www.ajol.info) were consulted for the purpose of gathering information and data which are published in local journals only.

\section{Results \\ Data extraction}

Based on the online researches in databases, a total of 501 articles were identified. Redundant articles were removed (Fig. 1). All abstracts were collected, and titles and abstracts 


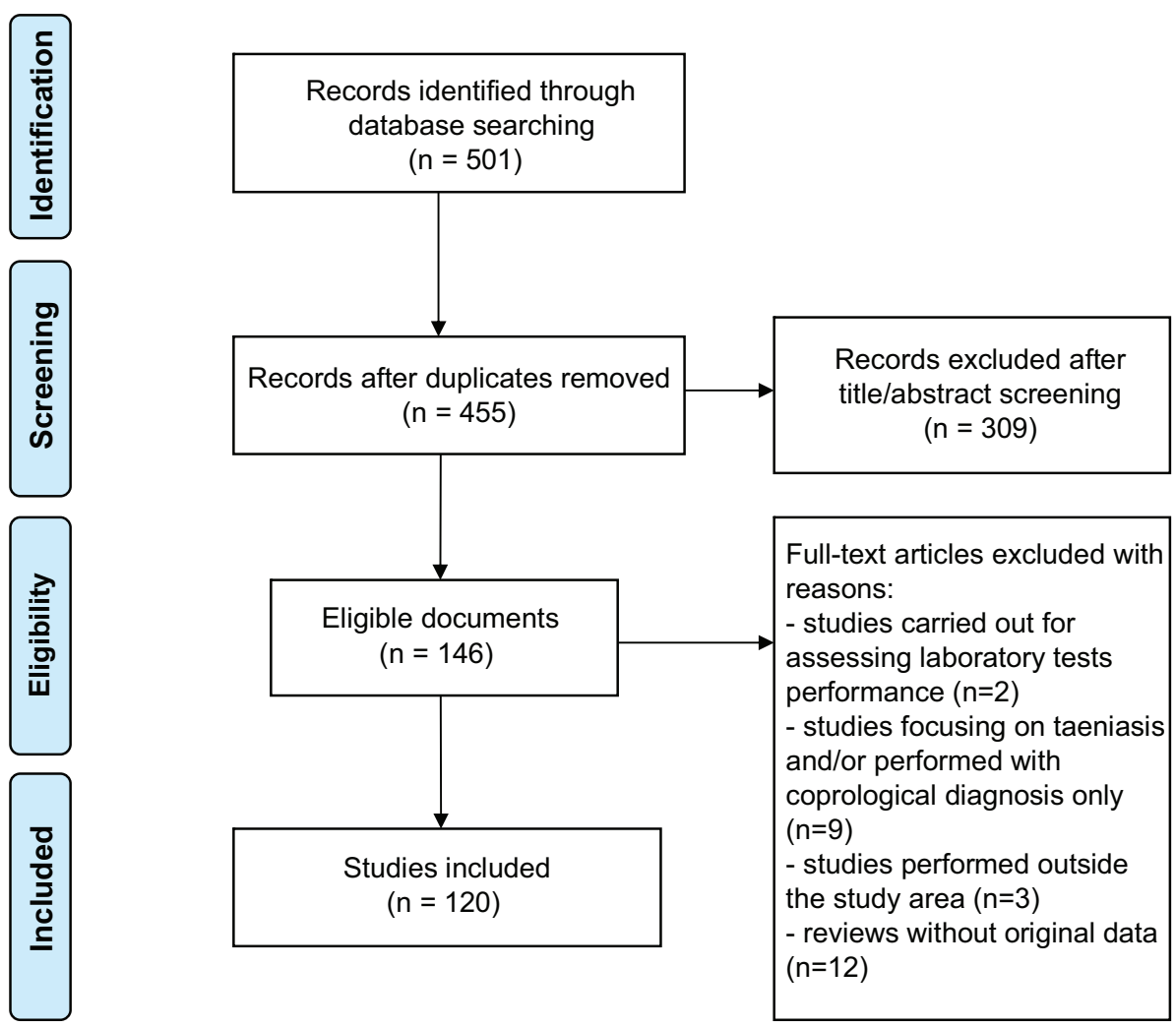

Figure 1. Workflow followed to identify articles in databases.

Table 1. Summary of publications available (case reports and epidemiological studies).

\begin{tabular}{|c|c|c|c|c|}
\hline $\begin{array}{l}\text { Country } \\
\text { name }\end{array}$ & Porcine cysticercosis & Human cysticercosis & Neurocysticercosis & $\begin{array}{l}\text { No. of references } \\
\text { (total: 120) }\end{array}$ \\
\hline Benin & {$[60,5,7]$} & $\begin{array}{c}{[123,2,64,92,56,11} \\
55,12,33,25]\end{array}$ & {$[2,13,10]$} & 16 \\
\hline Burkina Faso & $\begin{array}{c}{[32,53,7,110,63,73,} \\
71,39]\end{array}$ & $\begin{array}{c}{[29,90,18,28,52,68} \\
18,89,25]\end{array}$ & $\begin{array}{c}{[79,37,87,48,67} \\
121,119,57,84,104]\end{array}$ & 27 \\
\hline Ghana & $\begin{array}{c}{[8,97,20,91,7,97} \\
94,83,10]\end{array}$ & {$[21]$} & - & 10 \\
\hline $\begin{array}{l}\text { Côte } \\
\text { d'Ivoire }\end{array}$ & {$[80,36,7]$} & {$[25,58]$} & {$[13,10,70,26,86,62]$} & 11 \\
\hline Nigeria & $\begin{array}{l}{[9,35,93,61,23,69} \\
45,46,65,4,7,75,44]\end{array}$ & $\begin{array}{c}{[116,45,22,81,25,} \\
70,1,75,15,115]\end{array}$ & - & 20 \\
\hline Senegal & {$[108,7]$} & {$[123,106,56,30]$} & {$[13,44,41]$} & 9 \\
\hline Togo & [118] & {$[42,43,82,56,25]$} & $\begin{array}{c}{[42,43,111,16,111} \\
13,19,118,6]\end{array}$ & 13 \\
\hline The Gambia & {$[108,7,96,98]$} & [103] & [107] & 6 \\
\hline Cape Verde & {$[74]$} & - & {$[102,27,98,95]$} & 5 \\
\hline $\begin{array}{l}\text { Guinea } \\
\text { Bissau }\end{array}$ & {$[35]$} & - & {$[114]$} & 2 \\
\hline Mali & - & - & {$[76]$} & 1 \\
\hline Guinea & - & - & - & 0 \\
\hline Liberia & - & - & - & 0 \\
\hline Niger & - & - & - & 0 \\
\hline Sierra Leone & - & - & - & 0 \\
\hline Mauritania & - & - & - & 0 \\
\hline
\end{tabular}

were analyzed manually. Accordingly, 146 articles were retained and full texts were obtained. Subsequently, certain articles were excluded based on the following criteria: (1) stud- ies carried out to assess laboratory test performance (unidentified samples); (2) studies focusing on taeniasis only and/or on T. saginata infection; (3) studies performed outside of the 
Table 2. Epidemiological data available.

\begin{tabular}{|c|c|c|c|c|c|c|c|}
\hline Country name & Year & $\begin{array}{l}\text { Prevalence } \\
\text { porcine } \\
\text { cystic. }(n)\end{array}$ & $\begin{array}{l}\text { Prevalence } \\
\text { human } \\
\text { cystic. }(n)\end{array}$ & $\begin{array}{c}\text { Prevalence NCC } \\
\text { among epileptic } \\
\text { patients }(n)\end{array}$ & $\begin{array}{l}\text { Methods of } \\
\text { diagnosis }\end{array}$ & $\begin{array}{c}\text { Case } \\
\text { reports }(n)\end{array}$ & Ref. No. \\
\hline \multirow[t]{5}{*}{ Benin } & 1993 & - & - & - & - & 1 & {$[11]$} \\
\hline & 1996 & - & $3.5(319)$ & $9.1(11)$ & Ab-ELISA & - & {$[2]$} \\
\hline & 1998 & - & $1.3(2625)$ & - & Ab-ELISA, EITB & - & [64] \\
\hline & 2010 & 0.22 & - & - & Post mortem*** & - & {$[60]$} \\
\hline & 2014 & $0.87(60.924)$ & - & - & Tongue*** & - & [59] \\
\hline \multirow[t]{9}{*}{ Burkina Faso } & 2000 & 0.57 & - & - & Meat*** & - & {$[32]$} \\
\hline & 2008 & - & - & - & - & 6 & [18] \\
\hline & 2009 & - & $10.3-1.4-0(532)$ & - & Ab-ELISA* & 1 & {$[29,85]$} \\
\hline & 2011 & $32.5-39.6(173-157)$ & - & - & Ag-ELISA* & - & {$[53]$} \\
\hline & 2012 & - & - & $2.2-1.5-0.2(888)$ & Ag-ELISA, CT scan & - & [79] \\
\hline & 2012 & - & $4.5(70)$ & - & Ag-ELISA & - & {$[90]$} \\
\hline & 2013 & - & - & - & - & 35 & [104] \\
\hline & 2014 & - & - & - & - & $3 * *$ & {$[57]$} \\
\hline & 2016 & - & 0-11.5 (3609) & - & $\mathrm{Ab}$ and $\mathrm{Ag}$-ELISA & - & [28] \\
\hline \multirow[t]{2}{*}{ Ghana } & 1999 & $11.7(60)$ & - & - & Post mortem & - & [97] \\
\hline & 2015 & $2.31(4121)$ & - & - & Post mortem & - & {$[8]$} \\
\hline \multirow[t]{5}{*}{ Côte d'Ivoire } & 1972 & - & - & - & - & 1 & [62] \\
\hline & 1978 & 2.5 & - & - & Tongue & - & {$[80]$} \\
\hline & 1980 & - & - & - & - & 1 & {$[26]$} \\
\hline & 1991 & 3.6 & - & - & Meat & - & [36] \\
\hline & 1999 & - & - & - & - & 4 & [86] \\
\hline \multirow[t]{9}{*}{ Nigeria } & 1980 & 1.76 & - & - & Post mortem & - & [35] \\
\hline & 1995 & $20.5(2358)$ & - & - & Post mortem & - & [93] \\
\hline & 2003 & - & - & - & - & 1 & {$[1]$} \\
\hline & 2010 & $5.85-14.4(205)$ & - & - & Tongue / Post mortem & - & [61] \\
\hline & 2012 & $3.2(247)$ & - & - & Post mortem & - & [23] \\
\hline & 2013 & - & $9.6(63)$ & - & Ab-ELISA & 1 & {$[15,116]$} \\
\hline & 2013 & $6.25(4380)$ & - & - & Post mortem & 1 & {$[69,115]$} \\
\hline & 2014 & $9.3(43)$ & - & - & Post mortem & - & [46] \\
\hline & 2015 & - & $14.3(300)$ & - & Ab-ELISA & - & [45] \\
\hline \multirow[t]{3}{*}{ Senegal } & 1976 & - & - & - & - & 2 & {$[44]$} \\
\hline & 2010 & $6.4-13.2(1705)$ & - & - & Ag-ELISA & - & [108] \\
\hline & 2011 & - & $11.9(403)$ & $23.3(43)$ & Ag-ELISA, EITB, CT scan & - & {$[106]$} \\
\hline \multirow[t]{5}{*}{ Togo } & 1989 & - & $2.4(5264)$ & $21.6(125)$ & Ag-ELISA & - & {$[42]$} \\
\hline & 1990 & - & $17(1000)$ & $29.5(1000)$ & Ag-ELISA & - & [43] \\
\hline & 2000 & - & $38(1000)$ & $135.29(1000)$ & Ag-ELISA & - & [16] \\
\hline & 2001 & - & - & - & - & 1 & [19] \\
\hline & 2015 & - & - & - & - & 143 & {$[82,111]$} \\
\hline The Gambia & 2010 & $4.8(371)$ & - & - & Ag-ELISA & - & [108] \\
\hline \multirow[t]{2}{*}{ Guinea Bissau } & 1980 & 18.4 & - & - & Post mortem & - & {$[35]$} \\
\hline & 2015 & - & - & - & - & $1 * *$ & [114] \\
\hline Mali & 2009 & - & - & - & - & 1 & [76] \\
\hline \multirow[t]{4}{*}{ Cape Verde } & 1995 & - & - & - & - & $1 * *$ & [104] \\
\hline & 2004 & - & - & - & - & $1 * *$ & {$[27]$} \\
\hline & 2013 & - & - & - & - & 1 & [98] \\
\hline & 2009 & - & - & - & - & 1 & [95] \\
\hline
\end{tabular}

* Ag-ELISA: Monoclonal antigen-detection enzyme-linked immunosorbent assay on serum; Ab-ELISA: Monoclonal antibody-detection enzyme-linked immunosorbent assay on serum;

${ }^{* *}$ Imported in Europe;

*** Tongue or meat or post mortem inspection;

(n) Number of subjects or animals examined.

study area; and (4) reviews without original data. Case reports were retained. Overall, 120 articles were included (Table 1). These articles, which cover only 11 out of the 16 countries of the region, concern the following topics: porcine cysticerco- sis (39), human cysticercosis (36), and neurocysticercosis (34). From these 120 articles, the following data were finally extracted and reported: country, year, prevalence, case reports and method of diagnosis (Table 2, Fig. 2). 


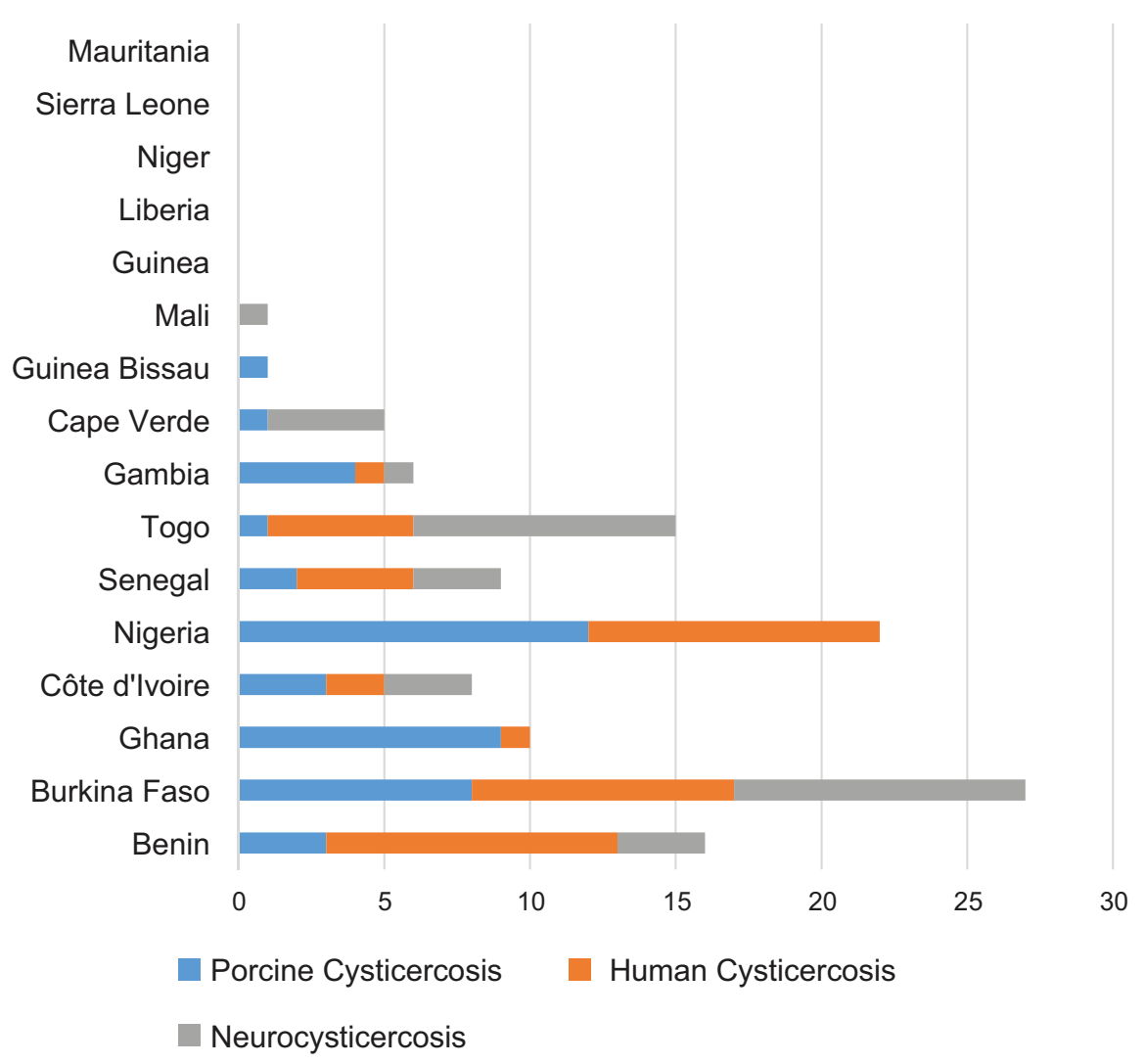

Figure 2. Summary of publications available by country.

\section{Epidemiological data on porcine cysticercosis}

Only 8 out of 16 countries of the region have reported porcine cysticercosis, namely Benin, Burkina Faso, Côte d'Ivoire, The Gambia, Ghana, Guinea Bissau, Nigeria, and Senegal (Table 2, Fig. 2). For some countries, data are clearly outdated, such as those for Guinea Bissau (1980), Togo (1990), and Côte d'Ivoire (1991).

Routine detection is based on tongue palpation or meat inspection, techniques characterized by low sensitivity $[17,32]$, which can lead to underestimation of the prevalence of cysticercosis. However, despite this low sensitivity, recent data obtained in slaughterhouses from post-mortem examinations have reported high levels of infection (from $5 \%$ to $15 \%$ ), especially in Nigeria [61]. In Benin, tongue examination reported infection under $10 \%[59,60]$. Some data were obtained through epidemiological studies using Ag-ELISA, highlighting infection between 5\% (The Gambia) and 40\% (Burkina Faso) $[53,108]$. In Nigeria, some chronological data are also available over the period between 1980 and 2014 [9]. During this time, prevalence increased from $1.76 \%$ in 1980 to $20.5 \%$ in 1995 , fell to $3.2 \%$ in 2010 and 2012 , but increased again to $9.3 \%$ in 2014 . No data are available for 1991-1994, 1996 and 2009 [46]. Records were obtained through postmortem examinations without a clear description of the protocol, with the consequence that the relevance of these fluctuations may be questioned.

In Burkina Faso, the first records (years 2000), based on meat inspection, showed a very low prevalence rate of
0.57\%; thereafter, no data were provided until 2011, when, based on the Ag-ELISA diagnostic technique, seroprevalence reached $39.6 \%$ [53].

\section{Human cysticercosis}

Seizures are the most frequent clinical manifestation of neurocysticercosis [106]. Data on neurocysticercosis are scarce and available only in terms of prevalence among epileptic patients and from the following five countries: Benin, Burkina Faso, Senegal, Nigeria and Togo (Table 2). Furthermore, Côte d'Ivoire, Mali and Cape Verde also declared case reports, though without systematic studies.

Aside from data concerning people with epilepsy, the first systematic studies on human cysticercosis were provided in 1989 and 1996 by Togo (2.4\%) and Benin (3.5\%), respectively. The most complete set of records relates to Burkina Faso and covers the years 2000-2016. According to the most recent data, the highest prevalence rates of human cysticercosis were found in Nigeria, with a $14.3 \%$ rate calculated on 300 persons (2015), in Senegal with an $11.9 \%$ rate calculated on 403 persons (2011), and in Burkina Faso, with an $11.5 \%$ rate calculated on 3609 persons (2016). For all these studies, serology (Ag-ELISA or Ab-ELISA, sometimes confirmed using Western Blot test-EITB) was used as the diagnosis method. Ag-ELISA was based on monoclonal antibodies that detect excretory/secretory circulating antigens of T. solium $[16,42$, $43,53,79,90,106,108]$. Ab-ELISA was performed for the 
screening of serum IgG antibodies to T. solium by using crude antigen from cysticerci of $T$. solium $[2,28,29,64]$ or the cysticercus ELISA Kit [45, 116]. The Ag-ELISA test detects viable cysts only, that is to say, current infection caused by T. solium metacestodes, whereas the presence of $\mathrm{IgG}$ antibodies indicates exposure to T. solium, but not necessarily an active infection. In the same line, most of the studies among epileptic patients refer to antigen detection and rarely to antibody detection or computed tomography (CT) scans (Senegal, Burkina Faso). Data are usually old, such as in Togo (19891990), with a recorded prevalence rate of $29.5 \%$. In 2011, and despite the predominance of the Muslim religion (which should involve reduced pork consumption), Senegal reported a rate of $23.3 \%$ among epileptic patients, which is remarkably high. During this period, studies in Senegal and Burkina Faso were performed in the following three phases: (1) "door-todoor" questionnaires, aimed at identifying the population at high risk for neurocysticercosis; (2) neurological examination of selected groups, aimed at confirming epileptic seizures or epilepsy in accordance with the 1989 Classification of Epilepsy Syndromes of the International League against Epilepsy [31]; and (3) serology (ELISA and EITB) and brain CT scans, to identify cysts and cysticercosis lesions.

\section{Discussion \\ Porcine cysticercosis}

In developing countries, livestock rearing is one of the main economic activities on which the poorest populations depend for food and income. Data on the prevalence of porcine T. solium cysticercosis are extremely scarce in West Africa and available only from a few countries. This review highlights that pork cysticercosis is largely present in most of the countries of the region. However, the burden of the animal disease (especially at local level), and its economic impact cannot be inferred from these records. While these statistics are mostly based on data provided by "official" abattoirs and slaughterhouses, it is well known that, in developing countries, most pigs are slaughtered outside these official facilities. Prevalence varies from country to country, but no data are available from Muslim countries (Niger, Mauritania, and Mali) where consumption of pork is extremely limited, with the exception of Burkina Faso, which is predominantly Muslim. However, in these countries, factors such as travel or employment of foreign housekeepers may be important sources of contamination.

Burkina Faso is estimated to have, by far, the highest prevalence of porcine cysticercosis (between $32.5 \%$ and $39.6 \%$ in 2011). Although modern pig-breeding was introduced to Burkina Faso at the beginning of the twentieth century, $80 \%$ of the pigs are still slaughtered by farmers at home and sold without prior meat inspection for cysticercosis [49], which constitutes a major risk for public health. Nigeria has the largest pig population in West Africa with 5 million animals [61]. The pig husbandry system is very similar to that used in Asia and Latin America [112], i.e. (1) intensive management, where pigs are confined within a shelter and are not allowed to move outside, (2) semi-intensive, where pigs are provided with shelter but are allowed to move outside to feed on natural vegetation, and (3) extensive or free range farming, where pigs are left to scavenge for all their food. The massive use of the free range farming system materially increases the risk of pigs being exposed to viable $T$. solium eggs and is certainly one of the factors that may have contributed to the spread of the disease in Nigeria [72]. Although a correlation between the development of T. solium eggs and environmental factors (e.g. rainfall, temperature and vegetation cover) has not yet been fully demonstrated, high temperature and humidity appear to have a positive impact on T. solium egg survival [109]. Furthermore, acidic soils in humid tropical areas may also facilitate egg survival [3, 77]. In addition, lack of regular inspections of meat (particularly in unregistered slaughter premises), despite the existence of laws and regulations, results in the consumption of unwholesome pork products [46]. In Ghana and neighboring countries (particularly Burkina Faso and Togo), the lack of cysticercosis data in the first decade of this century could be explained - at least in part - by the outbreaks of African swine fever (ASF) in 1999, which continued up to the years 2006-2007 and resulted in nearly $100 \%$ mortality in pigs [14].

These local variations appear to be largely attributable to the fact that statistics are based on the data provided by "official" abattoirs and slaughterhouses, whereas most of the pigs in endemic areas are slaughtered at home, without meat inspection. Clearly, the greatest challenge in controlling pork cysticercosis is the lack of regular reporting and data due to insufficient human resources to control slaughterhouses and herds. The organization of epidemiological surveys could thus be considered a prerequisite for monitoring the disease on a large scale. Chronological data are also needed to elaborate national strategies and launch information campaigns for rural populations.

\section{Human cysticercosis}

According to the World Health Organization (WHO), T. solium causes $30 \%$ of epilepsy cases in many endemic areas of Africa, Asia and Latin America, where people and roaming pigs live in close proximity [120]. Human cysticercosis is usually found in areas where porcine cysticercosis is widespread $[54,72]$.

The number of publications retrieved through this systematic search was relatively limited. This may be explained by a lack of diagnostic facilities, as well as low availability of expensive neuro-imaging devices. In humans, imaging is essential to confirm the diagnosis of neurocysticercosis, based on the revised diagnostic criteria proposed by Del Brutto et al. [38]. For NCC, this scarcity of reports could be related to the condition having a status of "unrecognized" disease. Most general practitioners seem to be unaware that this disease even exists in their own countries. When recorded, official data appear not to have been collected regularly and gaps of several years between reports are frequent. Some countries (e.g. Cape Verde, Guinea and Liberia) have no official data on cysticercosis. In developing countries, case reports of neurocysticercosis used to be the only source indicating local presence of the disease. They are sometimes reported from hospitals in Europe (e.g. Italy, France, and Portugal) treating travelers coming from the region [27, 57, 102]. 
In Togo (1989) and Nigeria (2015), where the prevalence of human cysticercosis was $21.6 \%$ and $14.3 \%$, respectively [42, 45], epidemiological studies have highlighted a strong association between epileptic seizures and cysticercosis. This is clearly the same situation as in Central Africa (e.g. a 2013 Cameroonian study) and in East Africa (e.g. a 2013 Rwandan study) [101], but not in The Gambia [107].

Epidemiological studies should be undertaken in all the countries of ECOWAS to fill these gaps.

\section{Conclusion}

Concerning the scarcity of available data, T. solium cysticercosis remains to date a largely underestimated, if not unrecognized disease in West Africa. Importantly, in certain countries where pig production is widespread (e.g. Côte d'Ivoire or Togo), the most recent reports concerning cysticercosis date back to the early 1990s.

The major challenge for cysticercosis recognition is the lack of biological diagnosis capacities and facilities in local health institutions. Furthermore, the use of traditional pig rearing systems and the lack of adequate meat inspections, together with poor sanitation and low hygiene (e.g. defecation in open air) [123], are circumstances that contribute substantially to spread of the disease.

When future studies on cysticercosis in West Africa are carried out, three series of factors will need to be taken into consideration as they could have influenced distribution of the disease throughout the region, namely: (1) socio-demographic factors, (2) geo-historical factors, and (3) climatic and environmental factors. Epidemiological studies should be promoted in the form of health partnerships and programs implemented within the context of the ECOWAS in order to ensure that comparative results are obtained.

Acknowledgements. Jihen Melki is supported by a grant from the PasteurInnov program. Eugène Koffi is supported by a grant from the PASRES program (Swiss cooperation). This project was also supported by a grant from the German Embassy and the Institut Pasteur de Côte d'Ivoire.

\section{Statements}

\section{Availability of data and material}

Freely available on the internet.

\section{Competing interests}

The authors declare that they have no competing interests.

\section{Author contributions}

JM carried out the search and wrote the text; EK and MB added information on veterinary aspects; MKS and EK added information on epidemiological aspects; RJ co-wrote the manuscript.

\section{References}

1. Adegbehingbe BO, Soetan EO, Adeoye AO. 2003. Case report, intraocular cysticercosis. West African Journal of Medicine, 22, 354-355.

2. Adjidé C, Bouteille B, Josse R, Adjidé-Szmidt V, Avodé D, Dumas M. 1996. Séroprévalence de la cysticercose dans la commune lacustre de Vekky, Département de l'Atlantique (Bénin). Bulletin de la Société de Pathologie Exotique, 89, 24-29.

3. Aina PO. 1993. Soil tillage in Africa: needs and challenges. Food and Agriculture Organization (FAO). Soils Bulletin, 69, http://www.fao.org/docrep/t1696e/t1696e07.htm.

4. Alonge DO, Fasanmi EF. 1979. A survey of abattoir data in northern Nigeria. Tropical Animal Health and Production, 11, 57-62.

5. Amaizo FB. 1980. The animal health situation in Togo. Bulletin de l'Office International des Épizooties, 92, 625-634.

6. Anayo N, Agbo L, Poko M, Kumako V, Apetse K, Belo M, Balogou A, Grunitzky KE. 2015. Neurocysticercose et VIH à propos de 4 cas observés aux CHU de Lomé. Journal de la Recherche Scientifique de 1'Université de Lomé, 17, 331-336.

7. Assana E, Lightowlers MW, Zoli AP, Geerts S. 2013. Taenia solium taeniosis/cysticercosis in Africa, risk factors, epidemiology and prospects for control using vaccination. Veterinary Parasitology, 195, 14-23.

8. Atawalna J, Ewura S, Mensah M. 2015. Prevalence and financial losses associated with porcine cysticercosis in the Kumasi Metropolis of Ghana. International Journal of Livestock Research, 5, 21-26.

9. Atehmengo NL, Nnagbo CS. 2014. Emerging animal parasitic diseases, a global overview and appropriate strategies for their monitoring and surveillance in Nigeria. Open Microbiology Journal, $8,87$.

10. Avode DG, Boco V, Bouteille B, Preux P, Houinato D, Zohoun T, Dumas M. 1998. Apport de la tomodensitométrie dans le diagnostic de la neurocysticercose. Médecine d'Afrique Noire, 45, 171-173.

11. Avode DG, Bouteille B, Avimadje M, Adjien C. 1993. Épilepsie, hypertension intracranienne, syndrome confusionnel et cysticercose cutanée. À propos d'un cas observé en milieu hospitalier au Bénin. Bulletin de la Société de Pathologie Exotique, 87, 186-188.

12. Avode DG, Capo-Chichi OB, Gandaho P, Bouteille B, Dumas M. 1995. Epilepsy caused by cysticercosis. A propos of a sociological and cultural investigation conducted at Savalou in Benin. Bulletin de la Société de Pathologie Exotique, 89, 45-47.

13. Avode DG. 1996. Épidémiologie de la neurocysticercose en Afrique Noire. Médecine d'Afrique Noire, 43, 8-9.

14. Babalobi OO, Olugasa BO, Oluwayelu DO, Ijagbone IF, Ayoade GO, Agbede SA. 2007. Analysis and evaluation of mortality losses of the 2001 African swine fever outbreak, Ibadan, Nigeria. Tropical Animal Health and Production, 39, 533-542.

15. Babalola O, Adu A, Akano AO. 2013. Ocular cysticercosis in a 32-year-old man in Abuja, ultrasonic features as an aid in diagnosis. Clinical Ophthalmology (Auckland, NZ), 7, 2275-2279.

16. Balogou AAK, Grunitzky KE, Beketi KA, Bouteille B, Dumas M. 2000. Cysticercose et épilepsie au nord du Togo dans le Tone. Revue Neurologique, 156, 270-273.

17. Banson KE, Nketsia-Tabiri J, Anno K, Dagbui EK. 2014. Economic and market analysis of swine rearing and pork production in Ghana. Journal of Life Sciences, 2014(8), 699-708. 
18. Barro-Traoré F, Ouédraogo M, Sanou-Lamien A, LompoGoumbri O, Bassolé A, Sawadogo S, Korsaga-Somé N, Niamba P, Traoré A. 2008. Cysticercose sous-cutanée généralisée, à propos de six cas au Burkina Faso. Bulletin de la Société de Pathologie Exotique, 101, 17-19.

19. Belo M, Grunitzky EK, Balogou A, Kowu L. 2001. Cerebral cysticercosis and headache in a young Togolese woman. Revue Neurologique, 157, 433.

20. Berglee R. 2012. World Regional Geography, People, Places and Globalization. World Regional Geography, People, Places and Globalization. https://doi.org/10.24926/8668.2701

21. Bimi L, Laar AK, Anto F. 2012. Prevalence and risk factors of taeniasis in the Bunkpurugu-Yunyoo District of Northern Ghana. Journal of Bacteriology and Parasitology, 3, 129.

22. Biu AA, Hena SA. 2008. Prevalence of human taeniasis in Maiduguri, Nigeria. International Journal of Biomedical Science, 4, 25-27.

23. Biu AA, Ijudai J. 2012. Prevalence and morphometric studies on porcine cysticercosis in Adamawa State, Nigeria. Sokoto Journal of Veterinary Sciences, 10, 28-31.

24. Boafo-Arthur K. 2008. Democracy and stability in West Africa, the Ghanaian experience. Department of Peace and Conflict Research, Uppsala University.

25. Bouteille B. 2014. Épidémiologie de la cysticercose et de la neurocysticercose. Médecine et Santé Tropicales, 24, 367374.

26. Bullock A. 1980. La cysticercose cérébrale. À propos d'une observation clinique, électrique et anatomique. Medical Thesis, Abidjan, Côte d'Ivoire, 75 p.

27. Canas NM, Calado SL, Vale J. 2004. Treatment of racemose neurocysticercosis of the spine. Revista de Neurologia, 40, 544-547.

28. Carabin H, Millogo A, Cissé A, Gabriël S, Sahlu I, Dorny P, Bauer C, Tarnagda Z, Cowan LD, Ganaba R. 2015. Prevalence of and factors associated with human cysticercosis in 60 villages in three provinces of Burkina Faso. PLoS Neglected Tropical Diseases, 9, e0004248.

29. Carabin H, Millogo A, Praet N, Hounton S, Tarnagda Z, Ganaba R, Dorny P, Nitiéma P, Cowan LD. 2009. Seroprevalence to the antigens of Taenia solium Cysticercosis among residents of three villages in Burkina Faso: A cross-sectional study. PLoS Neglected Tropical Diseases, 31, e555.

30. Collomb H, Larivière M, Philippe Y, Ayats H. 1964. A focus of cysticercosis in Basse Casamance, Senegal. Bulletins et Mémoires de l'École Préparatoire de Médecine et de Pharmacie de Dakar, 12, 148-155.

31. Commission on Classification and Terminology of the International League against Epilepsy. 1989. Proposal for revised classification of epilepsies and epileptic syndromes. Epilepsia, 30, 389-399.

32. Coulibaly ND, Yameogo KR. 2000. Prevalence and control of zoonotic diseases, collaboration between public health workers and veterinarians in Burkina Faso. Acta Tropica, 76, 5357.

33. Crepin S, Houinato D, Nawana B, Avode GD, Preux PM, Desport JC. 2007. Link between epilepsy and malnutrition in a rural area of Benin. Epilepsia, 48, 1926-1933.

34. Cristofori R, Ferrari S (Eds.). 2016. Law and religion in the 21 st century, relations between states and religious communities. Routledge. p. 406.

35. Dada BJO. 1980. Taeniasis, cysticercosis and echinococcosis/ hydatidosis in Nigeria, III - prevalence of bovine and porcine cysticercosis, and hydatid cyst infection based on joint examination of slaughtered food animals. Journal of Helminthology, 54, 293-297.
36. Danho T. 1991. Cysticercose musculaire et trichinellose du porc : cas particulier de la Côte d'Ivoire. Veterinary Medicine Thesis, École Nationale Vétérinaire de Lyon, 75 p. http:// www.sudoc.fr/04349367X.

37. Debouverie M, Kaboré J, Weber M, Duboz P, Vaugelade J. 1993. Épidémiologie de l'épilepsie au Burkina Faso, à propos d'une enquête en milieu rural. Neurologie Tropicale, 57-61.

38. Del Brutto OH, Nash TE, White AC, Rajshekhar V, Wilkins PP, Singh G, Garcia HH. 2017. Revised diagnostic criteria for neurocysticercosis. Journal of the Neurological Sciences, 372, 202-210.

39. Dermauw V, Ganaba R, Cissé A, Ouedraogo B, Millogo A, Tarnagda Z, Van Hul A, Gabriël S, Carabin H, Dorny P. 2016. Taenia hydatigena in pigs in Burkina Faso, A cross-sectional abattoir study. Veterinary Parasitology, 230, 9-13.

40. UN DESA. 2015. World population prospects, the 2017 revision, key findings and advance tables. Working Paper No. 2015. https://www.compassion.com/multimedia/world-population-prospects.pdf.

41. Druet-Cabanac M, Ramanankandrasana B, Bisser S, Dongmo L, Avode G, Nzisabira L, Dumas M, Preux PM. 2002. Taenia solium cysticercosis in Africa. Taenia solium Cysticercosis: From basic to clinical science, 129.

42. Dumas M, Grunitzky E, Deniau M, Dabis F, Bouteille B, Belo M, Pestre-Alexandre M, Catanzano G, Darde ML, D'Almeida M. 1989. Epidemiological study of neurocysticercosis in northern Togo West Africa. Acta Leidensia, 57(2), 191-196.

43. Dumas M, Grunitzky K, Dabis F, Deniau M, Bouteille B, Belo M, Pestre-Alexandre M, Catanzano G, Darde ML, D'Almeida M. 1990. Cysticercose et neurocysticercose : enquête épidémiologique dans le nord du Togo. Bulletin de la Société de Pathologie Exotique, 83, 263-274.

44. Dumas M, N'diaye IP, Daumens JM, Gueye M. 1976. Cysticercose cérébrale (deux nouveaux cas sénégalais). Bulletin de la Société Médicale d'Afrique Noire de Langue Française, 21, 203.

45. Edia-Asuke AU, Inabo HI, Mukaratirwa S, Umoh VJ, Whong CM, Asuke S, Ella EE. 2015. Seroprevalence of human cysticercosis and its associated risk factors among humans in areas of Kaduna metropolis, Nigeria. Journal of Infection in Developing Countries, 9, 799-805.

46. Edia-Asuke AU, Inabo HI, Umoh VJ, Whong CM, Asuke S, Edeh RE. 2014. Assessment of sanitary conditions of unregistered pig slaughter slabs and post mortem examination of pigs for Taenia solium metacestodes in Kaduna metropolis, Nigeria. Infectious Diseases of Poverty, 3, 45.

47. Ellis S. 2006. The mask of anarchy updated edition, the destruction of Liberia and the religious dimension of an African civil war. New York University Press.

48. Engels D, Urbani C, Belotto A, Meslin F, Savioli L. 2003. The control of human (neuro) cysticercosis, which way forward? Acta Tropica, 87, 177-182.

49. FAO. 2012. Secteur Porcin Burkina Faso. Revues nationales de l'élevage de la division de la production et de la santé animales de la FAO. No. 1. Rome. http://www.fao.org/3/ai2567f.pdf.

50. Ferguson W. 1985. Integrating crops and livestock in West Africa. FAO Animal Production and Health Paper. 41.

51. Flisser A, Rodríguez-Canul R, Willingham AL. 2006. Control of the taeniosis/cysticercosis complex, future developments. Veterinary Parasitology, 139, 283-292.

52. Fortunato S, Castagna B, Monteleone MR, Pierro R, Cringoli $\mathrm{G}$, Bruschi F. 2014. Parasite prevalence in a village in Burkina Faso, the contribution of new techniques. Journal of Infection in Developing Countries, 8, 670-675. 
53. Ganaba R, Praet N, Carabin H, Millogo A, Tarnagda Z, Dorny P, Hounton S, Sow A, Nitiéma P, Cowan LD. 2011. Factors associated with the prevalence of circulating antigens to porcine cysticercosis in Three Villages of Burkina Faso. PLoS Neglected Tropical Diseases, 5, e927.

54. García HH, Gonzalez AE, Evans CAW, Gilman RH. 2003. Taenia solium cysticercosis. Lancet, 362, 547-555.

55. Geerts S, Zoli A, Nguekam JP, Brandt J, Dorny P. 2004. The taeniasis-cysticercosis complex in West and Central Africa. Southeast Asian Journal of Tropical Medicine and Public Health, 35, 262-265.

56. Geerts S, Zoli A, Willingham L, Brandt J, Dorny P. 2002. Taenia solium cysticercosis in Africa: an underrecognised problem, in Cestode Zoonoses: Echinococcosis and Cysticercosis an Emergent and Global Problem, Craig P, Pawlowski Z, Editors. IOS Press, Amsterdam. p. 13-23.

57. Giordani MT, Tamarozzi F, Cattaneo F, Brunetti E. 2014. Three cases of imported neurocysticercosis in Northern Italy. Journal of Travel Medicine, 21, 17-23.

58. Giordano C. 1976. Cerebral cysticercosis with mental confusion. EEG and clinico-anatomical study. Médecine d'Afrique Noire, 23, 43-51.

59. Goussanou JSE, Korsak N, Saegerman C, Youssao AKI, Azagoun E, Farougou S, Gabriël S, Dorny P, Kpodekon MT. 2014. Assessment of routine inspection method for diagnostic of porcine cysticercosis in south east benin by using meat inspection records and Ag-ELISA Test. International Journal of Animal and Veterinary Advances, 6, 80-86.

60. Goussanou JSE. 2010. Évaluation des procédés d'abattage et de la qualité microbiologique des carcasses de porcs locaux des Abattoirs de Cotonou-Porto-Novo et des tueries de Cotonou et de Godomey. Mémoire de fin de formation de master en normes, Contrôle de qualité et technologie alimentaire. UAC, Bénin

61. Gweba M, Faleke OO, Junaidu AU, Fabiyi JP, Fajinmi AO. 2010. Some risk factors for Taenia solium cysticercosis in semi-intensively raised pigs in Zuru, Nigeria. Veterinaria Italiana, 46, 57-67.

62. Heroin P, Loubière R, Doucet J. 1972. Un cas de cysticercose sous-cutanée en Côte d'Ivoire. Revue Médicale de Côte d'Ivoire, 8, 26.

63. Hotez PJ. 2010. A plan to defeat neglected tropical diseases. Scientific American, 302, 90-96.

64. Houinato D, Ramanankandrasana B, Adjidé C, Melakul Z, Josse R, Avodé G, Dumas M, Bouteille B. 1998. Seroprevalence of cysticercosis in Benin. Transactions of the Royal Society of Tropical Medicine and Hygiene, 92, 621-624.

65. Ikeme MM. 1970. Pig parasites of Nigeria with emphasis on the local breed. Veterinary Record, 86, 644 .

66. International Monetary Fund. 2016. World Economic Outlook, Subdued Demand, Symptoms and Remedies. Washington, October, DOI: http://dx.doi.org/10.5089/ 9781475550801.081.

67. Kaboré J, Lengani A, Drabo YJ, Melaku Z, Preux PM, N'Diaye IP. 1995. Clinical aspects of seizure disorders at Ouagadougou-Burkina Faso, retrospective study of 532 cases. African Journal of Neurological Sciences, 14, 24-26.

68. Kanobana K, Praet N, Kabwe C, Dorny P, Lukanu P, Madinga J, Mitashi P, Verwijs M, Lutumba P, Polman K. 2011. High prevalence of Taenia solium cysticerosis in a village community of Bas-Congo, Democratic Republic of Congo. International Journal for Parasitology, 41, 1015-1018.

69. Karshima N, Bobbo A, Udokainyang A, Salihu A. 2013. Taenia solium Cysticercosis in pigs slaughtered in IBI local government area of Taraba State, Nigeria. Journal of Animal and Veterinary Advances, 3, 109-113.

70. Kaz PD, Gam KP. 2013. Survey of Cysticercus (Bladder Worm) in meat sold for consumption in Bukuru, Plateau State Nigeria. Academic Journal of Interdisciplinary Studies, 2, 45.

71. Kpoda NW, Oueda A, Somé YSC, Cissé G, Maïga AH, Kabré GB. 2015. Physicochemical and parasitological quality of vegetables irrigation water in Ouagadougou city, BurkinaFaso. African Journal of Microbiology Research, 9, 307-317.

72. Kungu JM, Dione MM, Ocaido EjobiF. 2015. Status of Taenia solium cysticercosis and predisposing factors in developing countries involved in pig farming. International Journal of One Health, 1, 6-13.

73. Lekule FP, Kyvsgaard NC. 2003. Improving pig husbandry in tropical resource-poor communities and its potential to reduce risk of porcine cysticercosis. Acta Tropica, 87, 111-117.

74. Lopes Antunes AC, Vieira S, Malta M, Nunes T, Vaz Y. 2015. Swine production on Maio Island, Cape Verde, a household survey. Revista Portuguesa de Ciencias Veterinarias, 110, 155-159.

75. Magaji AA, Oboegbulem SI, Daneji AI, Garba HS, Salihu MD, Junaidu AU, Mohammed AA, Lawal M, Aminu S, Yakubu Y, Mamuda A. 2011. Incidence of Hydatid cyst disease in food animals slaughtered at Sokoto Central Abbatoir, Sokoto State, Nigeria. Veterinary World, 4, 197200.

76. Maïga Y, Diallo M, Bouteille B, Konate A, Diarra M, Maïga M, Marjolet M. 2009. À propos d'un cas autochtone de neurocysticercose au Mali (premier cas de la littérature ?) Bulletin de la Société de Pathologie Exotique, 102, 211214.

77. Maya C, Torner-Morales FJ, Lucario ES, Hernández E, Jiménez B. 2012. Viability of six species of larval and nonlarval helminth eggs for different conditions of temperature, $\mathrm{pH}$ and dryness. Water Research, 46, 4770-4782.

78. Millennium Development Goals report. 2015. New York, United Nations. http://www.un.org/millenniumgoals/ 2015_MDG_Report/pdf/MDG2015, rev (July 1). Accessed 19 July 2017.

79. Millogo A, Nitiéma P, Carabin H, Boncoeur-Martel MP, Rajshekhar V, Tarnagda Z, Praet N, Dorny P, Cowan L, Ganaba R, Hounton S, Preux PM, Cissé R. 2012. Prevalence of neurocysticercosis among people with epilepsy in rural areas of Burkina Faso. Epilepsia, 53, 2194-2202.

80. Mishra GS, N'Depo AE. 1978. Les cysticerques des animaux abattus à l'abattoir de Port-Bouet (Abidjan), (Côte d'Ivoire). Revue d'Élevage et de Médecine Vétérinaire des Pays Tropicaux, 31, 431-436.

81. Mogaji HO, Adeniran AA, Fagbenro MT, Olabinke DB, Abe EM, Ekpo UF. 2016. Prevalence of Human Taeniasis in Odeda Area of Ogun State, Nigeria. International Journal of Tropical Disease and Health, 17, 1-8.

82. Mouhari-Toure A, N'Timon B, Kumako V, Darre T, Saka B, Tchaou M, Amegbor K, Kombate K, Balogou AA, Pitche P. 2015. Cysticercose disséminée, trois cas au Togo. Bulletin de la Société de Pathologie Exotique, 108, 165-170.

83. Mutua FK, Randolph TF, Arimi SM, Kitala PM, Githigia SM, Willingham AL, Njeruh FM. 2007. Palpable lingual cysts, a possible indicator of porcine cysticercosis, in Teso District, Western Kenya. Journal of Swine Health and Production, 15, 206-212.

84. Napon C, Maïga Y, Diallo O, Kaboré J. 2010. Infectious ventriculitis in relation with neurocysticercosis in Burkina Faso. Revue Neurologique, 167, 632-634. 
85. Napon C, Ouédraogo D, Diallo O, Kapto O, Kabore J. 2009. Syndrome de Wallenberg et neurocysticercose, à propos d'un cas à Ouagadougou, Burkina Faso. Bulletin de la Société de Pathologie Exotique, 102, 5-6.

86. N'Dri K, Thera M, Bedi MO, Konan A, Ettien F, Zunon-Kipre E, Burdin-Mensah GD, Abby CB, Keita AK. 1999. Contribution of computed tomography in the diagnosis of symptomatic epilepsy. Cahiers Santé, 9, 61-64.

87. Nettle D. 1996. Language diversity in West Africa, An ecological approach. Journal of Anthropological Archaeology, $15,403-438$.

88. Network, African Trypanotolerant Livestock. 1987. Livestock production in tsetse-affected areas of Africa. In: Proceedings of a meeting held, 23, 27.

89. Niamba P, Faye O, Traoré A, Barro-Traoré F, Gaulier A. 2006. Cutaneous nodules of cysticercosis. Presse médicale (Paris, France: 1983), 35, 435-436.

90. Nitiéma P, Carabin H, Hounton S, Praet N, Cowan LD, Ganaba R, Kompaoré C, Millogo A. 2012. Prevalence casecontrol study of epilepsy in three Burkina Faso villages. Acta Neurologica Scandinavica, 126, 270-278.

91. Nonterah EW, Asenso NT, Emikpe BO, Asare DA. 2015. Consumer preference for swine offals and its health implications in Kumasi, Ghana. Animal Research International, 12, 2305-2310.

92. Nsengiyumva G, Druet-Cabanac M, Ramanankandrasana B, Bouteille B, Nsizabira L, Preux PM. 2003. Cysticercosis as a major risk factor for epilepsy in Burundi, East Africa. Epilepsia, 44, 950-955.

93. Onah DN, Chiejina SN. 1995. Taenia solium cysticercosis and human taeniasis in the Nsukka area of Enugu State, Nigeria. Annals of Tropical Medicine and Parasitology, 89, 399-407.

94. Otupiri E, Adam M, Laing E, Akanmori BD. 2000. Detection and management of zoonotic diseases at the Kumasi slaughterhouse in Ghana. Acta Tropica, 76, 15-19.

95. Pamplona J, Braz A, Conceição C, Rios C, Reis J. 2015. A rare case of racemose neurocysticercosis and its complications. Neuroradiology Journal, 28, 418-420.

96. Penrith ML, Mukaratirwa S, Lekule F. 2009. Cysticercosis working group in Eastern and Southern Africa-6th General Assembly. Journal of the South African Veterinary Association, 80, 206-207.

97. Permin A, Yelifari L, Bloch P, Steenhard N, Hansen NP, Nansen P. 1999. Parasites in cross-bred pigs in the Upper East region of Ghana. Veterinary Parasitology, 87, 63-71.

98. Pinto S, Prata F, Moreno T. 2013. Acute bilateral ptosis as the sole manifestation of neurocysticercosis in a child. Pediatric Neurology, 49, 518-519.

99. Roman G, Sotelo J, Del Brutto O, Flisser A, Dumas M, Wadia N, Trelles L. 2000. A proposal to declare neurocysticercosis an international reportable disease. Bulletin of the World Health Organization, 78, 399-406.

100. Rosenberg P, Kano M, Ludford I, Prasad A, Thomson H. 2016. Global report on urban health, Equitable, healthier cities for sustainable development. World Health Organization.

101. Rottbeck R, Nshimiyimana JF, Tugirimana P, Düll UE, Sattler J, Hategekimana JC, Dieckmann S. 2013. High prevalence of cysticercosis in people with epilepsy in southern Rwanda. PLoS Neglected Tropical Diseases, 7, e2558.

102. Sangla S, De Broucker T, Abgrall S, Gauthier N. 1995. Infarctus cérébral révélateur d'une neurocysticercose. Revue Neurologique, 151, 277-280.
103. Sarti E, Schantz PM, Avila G, Ambrosio J, Medina-Santillan R, Flisser A. 2000. Mass treatment against human taeniasis for the control of cysticercosis, a population-based intervention study. Transactions of the Royal Society of Tropical Medicine and Hygiene, 94, 85-89.

104. Savadogo AA, Kaboré J, Cissé R. 2013. Clinical and CT-scan aspects of neurocysticercosis (NCC) at teaching hospital Yalgado Ouédraogo concerning 35 cases. Journal of the Neurological Sciences, 333, e60.

105. Schantz PM, Wilkins PP, Tsang VCW. 1998. Immigrants, imaging and immunoblots, the emergence of neurocysticercosis as a significant public health problem, in Emerging infections 2. Scheld WM, Craig WA, Hughes JM, Editors. ASM Press: Washington. p. 213-241.

106. Secka A, Grimm F, Marcotty T, Geysen D, Niang AM, Ngale V, Boutche L, Van Marck E, Geerts S. 2011. Old focus of cysticercosis in a Senegalese village revisited after half a century. Acta Tropica, 119, 199-202.

107. Secka A, Grimm F, Victor B, Marcotty T, De Deken R, Nyan O, Herera O, Van Marck E, Geerts S. 2010. Epilepsy is not caused by cysticercosis in The Gambia. Tropical Medicine and International Health, 15, 476-479.

108. Secka A, Marcotty T, De Deken R, Van Marck E, Geerts S. 2010. Porcine cysticercosis and risk factors in The Gambia and Senegal. Journal of Parasitology Research, 2010, 823-892.

109. Singh G, Prabhakar S, (Eds). 2002. Taenia solium cysticercosis, from basic to clinical science. Wallingford, Oxon, UK: CABI Publishing.

110. Some L, Dembele Y, Ouedraogo M, Some BM, Kambire FL, Sangare S. 2006. Analysis of crop water use and soil water balance in Burkina Faso using CROPWAT. CEEPA Discussion Paper No. 36. Centre for Environmental Economics and Policy in Africa, University of Pretoria.

111. Sonhaye L, Tchaou M, Amadou A, Assih K, Kolou B, Adjenou K, N'dakena K. 2015. Valeur diagnostique de la tomodensitométrie dans la cysticercose cérébrale à Lomé. Pan African Medical Journal, 20, 67.

112. Steinfeld H, Wassenaar T, Jutzi S. 2006. Livestock production systems in developing countries, status, drivers, trends. Revue Scientifique et Technique, 25, 505-516.

113. Topp FargionJ. 2015. Language, script and symbol in West Africa. London: British Library.

114. Vaidya A, Singhal S, Dhall S, Manohar A, Mahajan H. 2013. Asymptomatic disseminated cysticercosis. Journal of Clinical and Diagnostic Research, 7, 1761-1763.

115. Valadas E, Badura R, Marques T, Neno M, Boura M, Filipa Sutre AF, Beato S, Grácio MA, Neves JC. 2015. A case of imported neurocysticercosis in Portugal. Journal of Infection in Developing Countries, 9, 114-117.

116. Weka RP, Ikeh EI, Kamani J. 2013. Seroprevalence of antibodies (IgG) to Taenia solium among pig rearers and associated risk factors in Jos metropolis, Nigeria. Journal of Infection in Developing Countries, 7, 67-72.

117. Wer T. 2014. Ebola virus disease in West Africa-the first 9 months of the epidemic and forward projections. New England Journal of Medicine, 371, 1481-1495.

118. White AC, Jr. 2000. Neurocysticercosis, updates on epidemiology, pathogenesis, diagnosis, and management. Annual Review of Medicine, 51, 187-206.

119. Winkler AS, Willingham AL, Sikasunge CS, Schmutzhard E. 2009. Epilepsy and neurocysticercosis in sub-Saharan Africa. Wiener klinische Wochenschrift, 121, 3-12. 
120. World Health Organization. 2014. Taeniasis/cysticercosis. Fact sheet $\mathrm{N}^{\circ} 376$. http://www.who.int/news-room/fact-sheets/ detail/taeniasis-cysticercosis.

121. World Health Organization. 2015. Landscape analysis, management of neurocysticercosis with an emphasis on low-and middle-income countries. WHO/HTM/NTD/NZD/2015.05.

122. Xue Y, Boone A, Taylor CM. 2012. Review of recent developments and the future prospective in West African atmosphere/land interaction studies. International Journal of Geophysics, 2012, 748-921.

123. Zoli A, Shey-Njila O, Assana E, Nguekam JP, Dorny P, Brandt J, Geerts S. 2003. Regional status, epidemiology and impact of Taenia solium cysticercosis in Western and Central Africa. Acta Tropica, 87, 35-42.

Cite this article as: Melki J, Koffi E, Boka M, Touré A, Soumahoro MK \& Jambou R. 2018. Taenia solium cysticercosis in West Africa status update. Parasite 25, 49.

\section{PARASTE}

An international open-access, peer-reviewed, online journal publishing high quality papers on all aspects of human and animal parasitology

Reviews, articles and short notes may be submitted. Fields include, but are not limited to: general, medical and veterinary parasitology; morphology, including ultrastructure; parasite systematics, including entomology, acarology, helminthology and protistology, and molecular analyses; molecular biology and biochemistry; immunology of parasitic diseases; host-parasite relationships; ecology and life history of parasites; epidemiology; therapeutics; new diagnostic tools.

All papers in Parasite are published in English. Manuscripts should have a broad interest and must not have been published or submitted elsewhere. No limit is imposed on the length of manuscripts.

Parasite (open-access) continues Parasite (print and online editions, 1994-2012) and Annales de Parasitologie Humaine et Comparée (1923-1993) and is the official journal of the Société Française de Parasitologie. http://parasite.edmgr.com/ 